Scientia Marina 71(3)

September 2007, 471-484, Barcelona (Spain)

ISSN: 0214-8358

\title{
Comparative study of gonadal development of Ruditapes philippinarum (Adams and Reeve) and Ruditapes decussatus (L.) (Mollusca: Bivalvia): Influence of temperature
}

\author{
MARINA DELGADO ${ }^{1}$ and ALEJANDRO PÉREZ-CAMACHO ${ }^{2}$ \\ ${ }^{1}$ Institut de Recerca i Tecnologia Agroalimentaries. Centre de Aqüicultura. Carretera del Poble Nou, Km 5.5. \\ E-43540 Sant Carles de la Rápita, Tarragona, Spain. E-mail: marina.delgado@irta.es \\ ${ }^{2}$ Instituto Español de Oceanografía. Muelle de Ânimas s/n, E-15001 A Coruña, Spain.
}

SUMMARY: Laboratory experiments were used to study the influence of temperature on the reproductive behaviour of two species of clam, Ruditapes decussatus and Ruditapes philippinarum, during their adaptation to the temperature conditions of Galician coastal waters. In both species the rate of gonadal development was directly related to the increase in temperature. At $14^{\circ} \mathrm{C}$ the reproductive behaviour was similar, both species needing over 2 months to mature. At $18^{\circ} \mathrm{C}$, the rate of gonadal development of $R$. philippinarum was greater than that of $R$. decussatus. Nevertheless, the results of this study confirm that both species have adapted perfectly to the temperature conditions of the Galician Rias, though certain differences between the reproductive behaviour of these species were detected. $R$. philippinarum accumulates oocytes prior to their partial or total emission, while in the case of $R$. decussatus gametes are liberated continuously. In the early phases of its development, the gonad of R.philippinarum is highly heterogeneous in nature, with up to 3 reproductive states being present at the same time, while in $R$. decussatus gonadal development is much more uniform. Another major difference concerns the phenomenon of reabsorption, common in $R$. philippinarum but very rare in $R$. decussatus. These characteristics may well result in a greater reproductive activity in $R$. philippinarum than in $R$. decussatus, and a longer reproduction period in the former. They may also represent a certain advantage for the adaptation of the foreign species ( $R$. philippinarum) over the native species $(R$. decussatus) to the temperature conditions of the Galician Rias.

Keywords: gonadal development, temperature, histology, Ruditapes decussatus, Ruditapes philippinarum, hermaphroditism.

RESUMEN: Estudio COMPARATIVO DEL DESARROllo GONADAl DE RUDITAPES PHILIPPINARUM (ADAMS AND REEVE) Y Ruditapes DeCussatus (L.) (Mollusca: Bivalvia): Influencia de La temperatura. - Se llevaron a cabo experiencias de laboratorio para estudiar la influencia de la temperatura en el comportamiento reproductivo de dos especies de almeja, $R$. philippinarum y $R$. decussatus, en su adaptación a las condiciones térmicas en las costas de Galicia. En ambas especies la tasa de desarrollo gonadal está directamente relacionada con el incremento de temperatura. A $14^{\circ} \mathrm{C}$ el comportamiento reproductivo es similar y ambas especies necesitan cerca de 2 meses para madurar. A $18^{\circ} \mathrm{C}$, la tasa de desarrollo gonadal de $R$. philippinarum es mayor que en $R$. decussatus. No obstante, los resultados de este estudio confirman que ambas especies se han adaptado perfectamente a las condiciones térmicas de las rías de Galicia, si bien, se detectan ciertas diferencias en su comportamiento reproductivo. Así, mientras $R$. philippinarum acumula ovocitos antes de su emisión parcial o total, en el caso e $R$. decussatus los gametos se liberan continuamente. En las primeras fases de su desarrollo, el aspecto de la gónada de $R$. philippinarum es muy heterogéneo, presentándose hasta 3 estados reproductivos simultáneamente, mientras que en $R$. decussatus el desarrollo gonadal es bastante más uniforme. Otra diferencia concierne al fenómeno de la reabsorción, común en $R$. philippinarum, pero muy raro en $R$. decussatus. Estas características pueden sustentar una mayor actividad reproductiva en $R$. philippinarum comparado con $R$. decussatus, y un mayor periodo reproductivo en el caso de la primera. Ello puede también representar una cierta ventaje adaptativa, de la especie foráneas (R.philippinarum) frente la especie nativa $(R$. decussatus), a las condiciones térmicas de las rías de Galicia.

Palabras clave: desarrollo gonadal, temperatura, histología, Ruditapes decussatus, Ruditapes philippinarum, hermafroditismo. 


\section{INTRODUCTION}

Ruditapes philippinarum is a species native to the Indian-Pacific region, but due to its high growth rates and its ability to tolerate a wide range of environmental conditions it was introduced into European Atlantic and Mediterranean coastal waters during the twentieth century for commercial cultivation, occupying a habitat that overlaps that of the native species $R$. decussatus.

Many studies have been published on the reproductive cycle of $R$. philippinarum in the natural environment both in the areas of origin of this species, like Japan (Ohba, 1959; Toba et al., 1993), and in parts of the world in which it has been introduced: the East Pacific (Holland and Chew, 1974), European coasts (Sarasquete et al., 1990; Ponurovsky and Yakovlev, 1992; RodríguezMoscoso et al., 1992; Meneghetti et al., 2004; Drummond et al., 2006) and African Atlantic coasts (Shaffee and Daouidi; 1991). The bibliography on $R$. decussatus, however, is not so extensive (PérezCamacho, 1980; Villalba et al., 1993; RodríguezMoscoso and Arnaíz, 1998).

Some studies have compared the reproductive behaviour of the two species in the natural environment (Beninger and Lucas, 1984; Laruelle et al., 1994; Xie and Burnell, 1994), but only very few have looked at the effects of temperature on the gonadal development of these species under controlled conditions, and then only with $R$. philippinarum (Mann, 1979; Toba and Miyama, 1995).

The purpose of this study was to compare the influence of temperature on the gonadal development of R. philippinarum and R. decussatus in the natural environment of the Galician coast, where the range of temperature is $13-18^{\circ} \mathrm{C}$ during the reproduction period of these two species. A particular aim was to determine the repercussion of any differences in the reproductive behaviour of the species with regard to temperature on their adaptation to the environmental conditions of Galician coastal waters.

\section{MATERIALS AND METHODS}

\section{Design and experimental conditions}

The experiments were carried out using adult specimens of Ruditapes decussatus $(37.9 \pm 1.0 \mathrm{~mm})$ and $R$. philippinarum $(36.3 \pm 2.2 \mathrm{~mm})$ collected from the intertidal environment from Ría de Arousa (Galician coast, Spain) in February of 2003.

The clams were placed in 121 plastic tanks in a flow-through circuit containing natural sea-water filtered through a $1 \mu \mathrm{m}$ mesh. Each of the two species was conditioned at each of two temperatures: 14 and $18^{\circ} \mathrm{C}$. The experiments were carried out with groups of 50 individuals.

A peristaltic pump was used to add food to the circuit. The food ration consisted of $0.5 \%$ dry weight of the microalga Isochrysis galbana clone T-ISO with regard to clam live weight. The microalgae were initially cultured in 61 jars and then transferred to 10001 tanks. Walne medium (Walne, 1966) and industrial fertiliser were used for the jar and tank cultivation, respectively. The microalgae were harvested during the stationary growth phase.

The total conditioning period was 78 days, with sampling being performed at the start of the experiment (0 days) and at days 32, 57 and 78. At each interval (including the initial sample at 0 days), groups of 10-12 individuals were sampled for histological study of gonadal development. A minimum of 4 specimens of each sex were taken in each sampling.

\section{Histology}

A conventional histology protocol was followed. The soft tissues were fixed with Bouin's fixative (Bancroft and Stevens, 1996), sealed in paraffin, and $4 \mu \mathrm{m}$ slices were taken. Para-Pak ${ }^{\circledR}$ Trichrome stain was used (Meridian Bioscience, Inc.). From each clam we obtained 3 slices corresponding to 3 different depths in the body.

The identification of the phases of gametogenic development in $R$. philippinarum was done using a modified scale from that proposed for this species by Holland and Chew (1974): Post-spawning and gonadal regression (Period of sexual rest) (Phase I), Initiation of gametogenesis (Phase II), Advanced gametogenesis (Phase III) and Reproduction period (Ripening and spawning period) (Phase IV). Gametogenic developmental phases in $R$. decussat$u s$ were identified as a function of the phases proposed for this species by Delgado and PérezCamacho (2005). The most relevant characteristics of the different phases of gonadal development of the two species are shown in Table 1. 
TABLE 1. - Phases of gonadal development of R. philippinarum and $R$. decussatus. Phase I (Post-spawning and gonadal regression; period of sexual rest), Phase II (Initiation of gametogenesis), Phase III (Advanced gametogenesis) and Phase IV (Ripening and spawning period; reproduction period).

\begin{tabular}{|c|c|c|c|}
\hline \multirow[t]{2}{*}{ Phases } & \multirow[t]{2}{*}{ Common characteristics } & \multicolumn{2}{|c|}{ Specific characteristics } \\
\hline & & R. philippinarum & $R$. decussatus \\
\hline Phase I & $\begin{array}{l}\text { Absence of gametes } \\
\text { Sex determination is no possible } \\
\text { Follicle walls are broken }\end{array}$ & $\begin{array}{l}\text { Severe infiltration of haemocytes } \\
\text { (reabsorption) }\end{array}$ & Absence of haemocytes infiltration \\
\hline Phase II & $\begin{array}{l}\text { The follicle walls are covered with developing } \\
\text { germinal cells } \\
\text { Abundance of vesicular cells and intragonadal } \\
\text { muscle tissue (reserve tissue) }\end{array}$ & $\begin{array}{l}\text { Infiltration of haemocytes } \\
\text { (reabsorption) }\end{array}$ & Absence of haemocytes infiltration \\
\hline Phase III & $\begin{array}{l}\text { Intense growth of oocytes (high presence of } \\
\text { pedunculated oocytes) in females } \\
\text { Increase of spermatozoids in the lumen of } \\
\text { acini in males } \\
\text { First signs of partial emission of gametes }\end{array}$ & $\begin{array}{l}\text { Highly heterogeneous development. } \\
\text { Coexistence of developing areas } \\
\text { with fully mature, half-empty and } \\
\text { reabsorption areas }\end{array}$ & Homogeneous development. \\
\hline Phase IV & $\begin{array}{l}\text { Generalised maturity of the whole gonad } \\
\text { Disappearance of reserve tissue } \\
\text { This phase ends with the total emission } \\
\text { of gametes }\end{array}$ & Weak reabsorption & \\
\hline
\end{tabular}

\section{Oocyte diameter frequency}

Gametogenic development in females is characterised by a considerable increase in oocyte size. Image analysis techniques (MicroImage software, Olympus) were used to measure the maximum diameter of the oocytes. Measurements of over 500 oocytes per specimen were obtained, corresponding to 3 different depths in the body of the clam, and size distribution frequency was determined for each specimen, each species and each experimental condition.

\section{Statistical analysis}

Statgraphics software (5.0) was used to analyse the experimental results. Analysis of oocyte size frequency distribution gave an indicator of the symmetry of the distribution (skewness) and a descriptor of the form of the distribution (kurtosis). In the case of a normal distribution, i.e. one in which the data are symmetrically distributed, skewness is zero; a positive skewness indicates that the left-hand tail of the distribution is greater, while a negative skewness implies that the distribution is heavier to the right, indicating a greater oocyte diameter. Kurtosis tells us whether the distribution of the data is more or less flat in comparison with a normal distribution. Kurtosis is zero for a normal distribution, positive in the case of a peaked distribution and negative if the distribution is flat.

To compare the effect of temperature on mean oocyte diameter, we used a t-test, at a minimum sig- nificance level of $p<0.05$. An F-test was used to check the homogeneity of the variances. All statistical analyses were performed according to the methods described in Zar (1974) and Snedecor and Cochran (1980).

\section{RESULTS}

\section{Histological study}

\section{Ruditapes philippinarum}

The experiment with $R$. philippinarum started with $60 \%$ of the individuals showing clear signs of gonadal regression, characteristic of a post-spawning phase (phase I; Figs. 1, 2 and 6). In these individuals, the majority of follicles showed the invasion of haemocytes that enfolded residual gametes corresponding to a previous reproduction period (Fig. 1b). The follicle walls were often very thin and broken. The remaining individuals $(40 \%)$ were in the initial phases of gametogenesis (phase II), and in some areas there were gonadal follicles in whose walls the new germinal lines were coming through.

Generally speaking, it is important to note the asynchronous state of gonadal development between individuals. This asynchrony is also expressed within the gonad of each individual, and areas with different degrees of maturity usually coexist in the same individual. Nevertheless, in accordance with the description given by Drummond et al. (2006) in their study of this species, each individual has been 

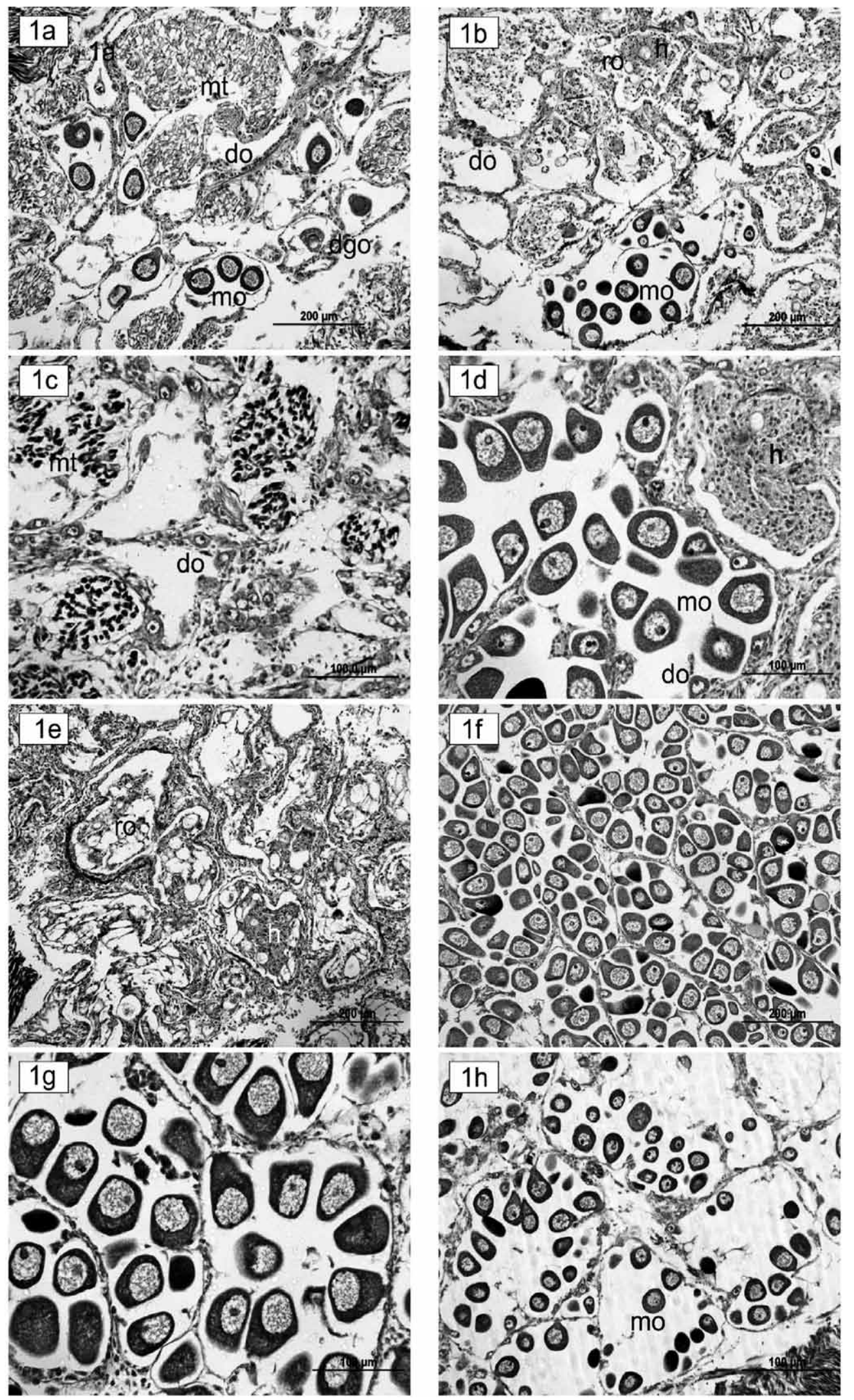

FIG. 1. - Gonadal development in females of R. philippinarum. 1a and $1 \mathrm{~b}$ beginning of the experiment. Experiment $14^{\circ} \mathrm{C}$ : $\left.1 \mathrm{c}\right) 32 \mathrm{days} ; 1 \mathrm{e}, 57$ days; $1 \mathrm{~g}, 78$ days. Experiment $18^{\circ} \mathrm{C}$ : $1 \mathrm{~d}, 32$ days; 1f, 57 days; $1 \mathrm{~h}, 78$ days. Abbreviations: do, developing oocyte; dgo, degenerative oocyte; $\mathrm{h}$, haemocytes; mo, mature oocyte; mt, muscle tissue; ro, reabsorbing oocyte. Scale bar: $100 \mu \mathrm{m}$ (photos: 1c, 1d, $1 \mathrm{~g}, 1 \mathrm{~h}) \mathrm{and} 200 \mu \mathrm{m}$ (photos: 1a, 1b, 1e, 1f). 

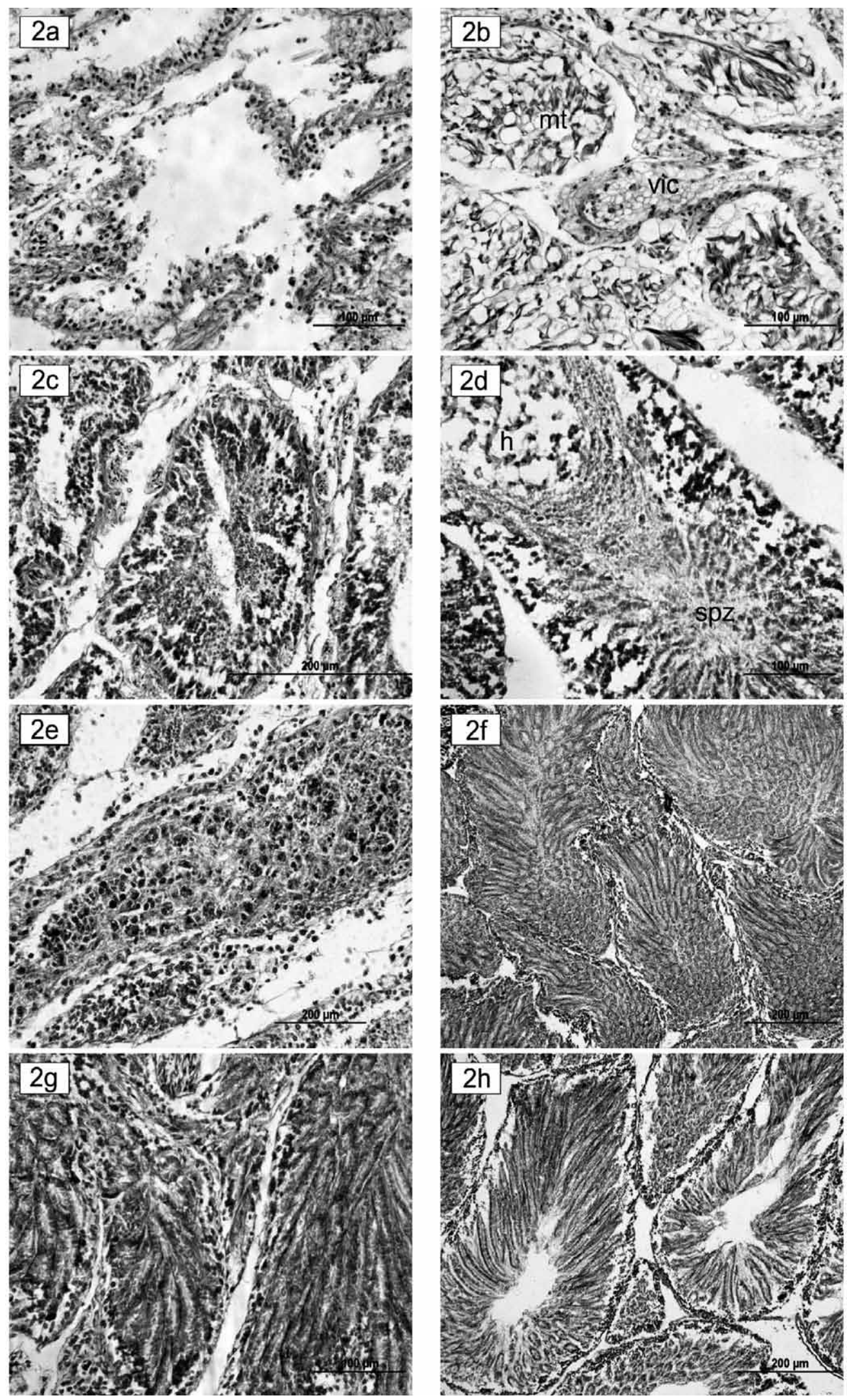

FIG. 2. - Gonadal development in males of $R$. philippinarum. $2 \mathrm{a}$ and $2 \mathrm{~b}$ beginning of the experiment. Experiment $14^{\circ} \mathrm{C}: 2 \mathrm{c}, 32 \mathrm{days} ; 2 \mathrm{e}, 57$ days; $2 \mathrm{~g}, 78$ days. Experiment $18^{\circ} \mathrm{C}$ : $2 \mathrm{~d}, 32$ days; $2 \mathrm{f}, 57$ days; $2 \mathrm{~h}, 78$ days. Abbreviations: h, haemocytes; mt, muscular tissue; spz, spermatozoids; vic, vesicular intrafollicular cells. Scale bar: $100 \mu \mathrm{m}$ (photos: 2a, 2b, 2d, 2g) and $200 \mu \mathrm{m}$ (photos: 2c, 2e, 2f, 2h). 
assigned the reproductive phase that corresponds to that of the greatest number of follicles.

Results show how a temperature increment accelerates the gonadal development of $R$. philippinarum. In this sense, we observe that 32 days after the start of the experiment at $14^{\circ} \mathrm{C} 70 \%$ of the individuals were still in phase II, showing no mature gametes (Figs. 1c, 2c and 6). However, at $18^{\circ} \mathrm{C}$ over $50 \%$ of the individuals had already reached phase IV and $36 \%$ showed the following features of phase III (Figs. 1d and 2d) in the same individual: empty follicles with walls showing intense gametogenic development, follicles full of fully mature gametes and spermatozoids in males, and areas in which partial spawning had taken place, characterised by very thin and broken follicle walls, loose mature oocytes and haemocyte infiltrations reabsorbing residual gametes.

After 57 days, $45 \%$ of the individuals kept at $14^{\circ} \mathrm{C}$ reached phase III but $28 \%$ of the sample were either still in the initiation of the gametogenesis phase (II), or even in that of sexual rest (9\%: phase I) (Figs. 1e and 2e). In the experiment at $18^{\circ} \mathrm{C}$, the overall appearance of the population indicated that $90 \%$ of the individuals were by then in the reproductive phase (IV).

By the 78th day of the conditioning period at $14^{\circ} \mathrm{C}$ the majority $(64 \%)$ of the individuals were in phase III. However, $36 \%$ of the individuals were well into phase IV (Figs. 1g and 2g). Nevertheless, at $18^{\circ} \mathrm{C}$ the females were fully mature $(100 \%$ in phase IV), this state of maturity applying to the complete gonad. In females, the follicles were bigger, and the mature oocytes filled them completely, giving them a polygonal shape (Fig. 1f). The males showed acines of considerable size and full of spermatozoids arranged in rosettes (Fig. 2f). Asynchronicity between individuals had almost disappeared in this final phase of maturation. All the individuals sampled showed clear signs of having suffered partial spawnings ( 1 and $2 \mathrm{~h}$ ), and occasional invasions of haemocytes were observed in areas where partial spawning may have occurred, although the frequency with which reabsorption phenomena appeared was noticeably lower than that of previous samplings.

Although $R$. philippinarum is a gonocoric species, we should nevertheless draw attention to the presence of 1 hermaphroditic individual. The individual, with a size of $36.2 \mathrm{~mm}$, was histologically examined after 78 days of conditioning. The female

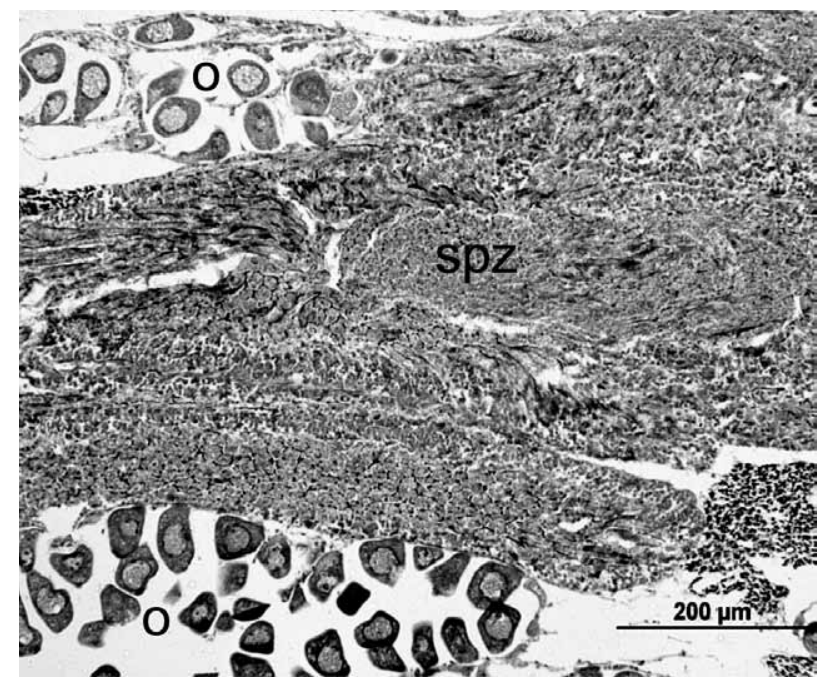

FIG. 3. - Detail of the gonad of the hermaphroditic individual of $R$. philippinarum after 78 days of conditioning. Abbreviations: o, oocytes; spz, spermatozoids. Scale bar: and $200 \mu \mathrm{m}$.

follicles, in an advanced phase of gametogenesis, occupied almost the entire gonad, in which there was an abundance of mature oocytes. In the central part of the gonad a mature male acine was detected, full of spermatozoids arranged in rosettes (Fig. 3), gametes of both sexes therefore being produced simultaneously.

\section{Ruditapes decussatus}

Initially $60 \%$ of the individuals were still in the period of sexual rest (phase I) and showed no evidence of gonadal development, so it was impossible to determine their sex (Figs. 4, 5 and 6). Totally empty areas appeared in some individuals, with an obvious post-spawning appearance in which the follicles, with no gametes either inside them or on their walls, were of great size and had thin and occasionally broken walls (Fig. 4a). In the remaining individuals (40\% in phase II), gonadal follicles were starting to make their way through the muscle fibres and the connective tissue that occupied the area from the digestive gland to the foot. In the females, the follicles were still not very large and their walls were both very active and full of immature cells. In the males, the germinal layers were very thick and showed the complete gametogenic process. No mature oocytes or spermatozoids were seen (Figs. $4 b, 5 a$ and $5 b)$.

Differences in the velocity of gonadal development were related to temperature increase with time. At $14^{\circ} \mathrm{C}, 32$ days after the start of the experimental period, $70 \%$ of the specimens were at phase II, with 

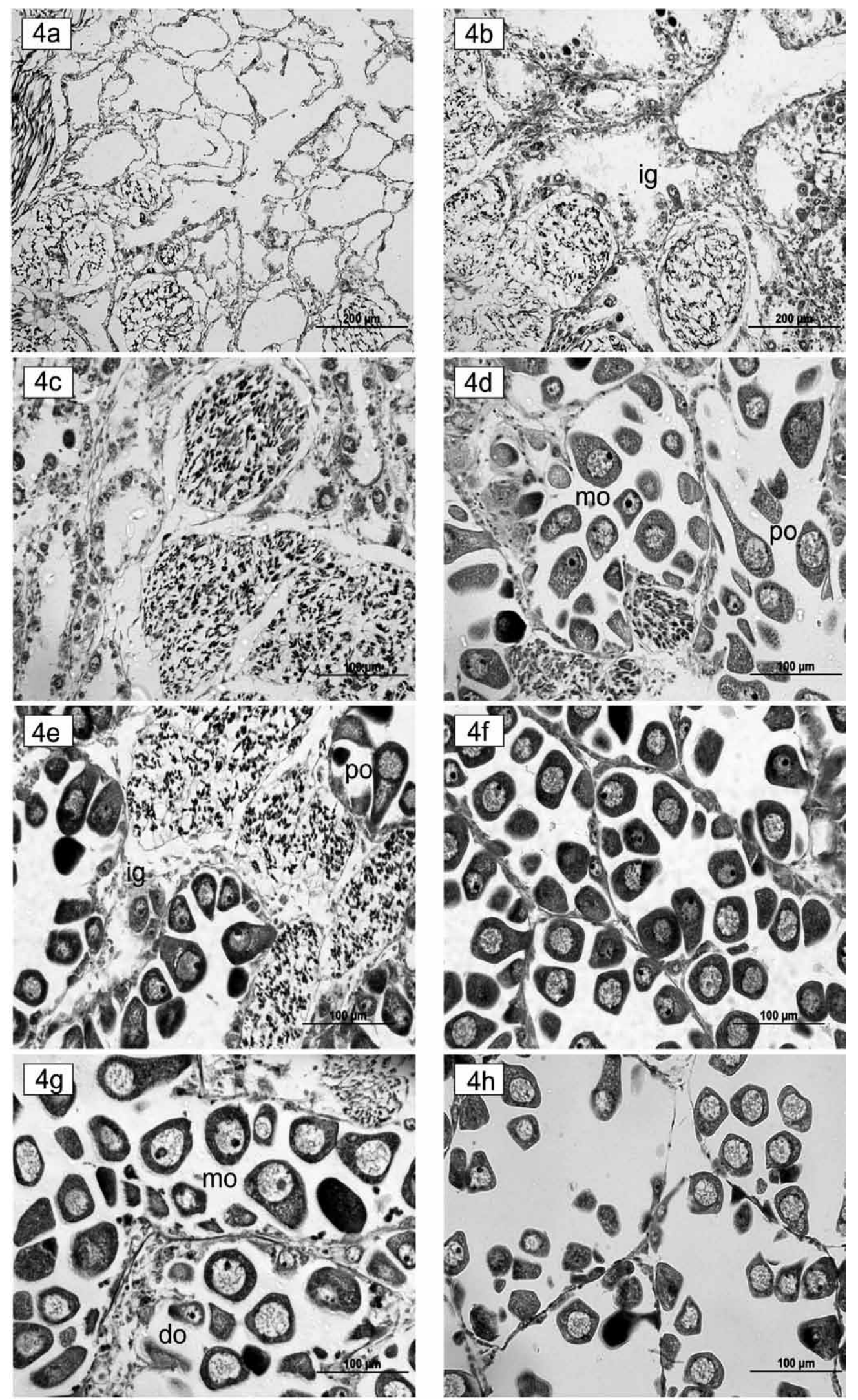

FIG. 4. - Gonadal development in females of R. decussatus. $4 \mathrm{a}$ and $4 \mathrm{~b}$ beginning of the experiment. Experiment $14^{\circ} \mathrm{C}: 4 \mathrm{c}, 32 \mathrm{days} ; 4 \mathrm{e}, 57$ days; $4 \mathrm{~g}, 78$ days. Experiment $18^{\circ} \mathrm{C}: 4 \mathrm{~d}, 32$ days; $4 \mathrm{f}, 57$ days; $4 \mathrm{~h}, 78$ days. Abbreviations: do, developing oocyte; ig, immature gametes; mo, mature oocyte; po, pedunculated oocyte. Scale bar: $100 \mu \mathrm{m}$ (photos: 4c, 4d, 4e, 4f, 4g, 4h) and $200 \mu \mathrm{m}$ (photos: 4a, 4b). 

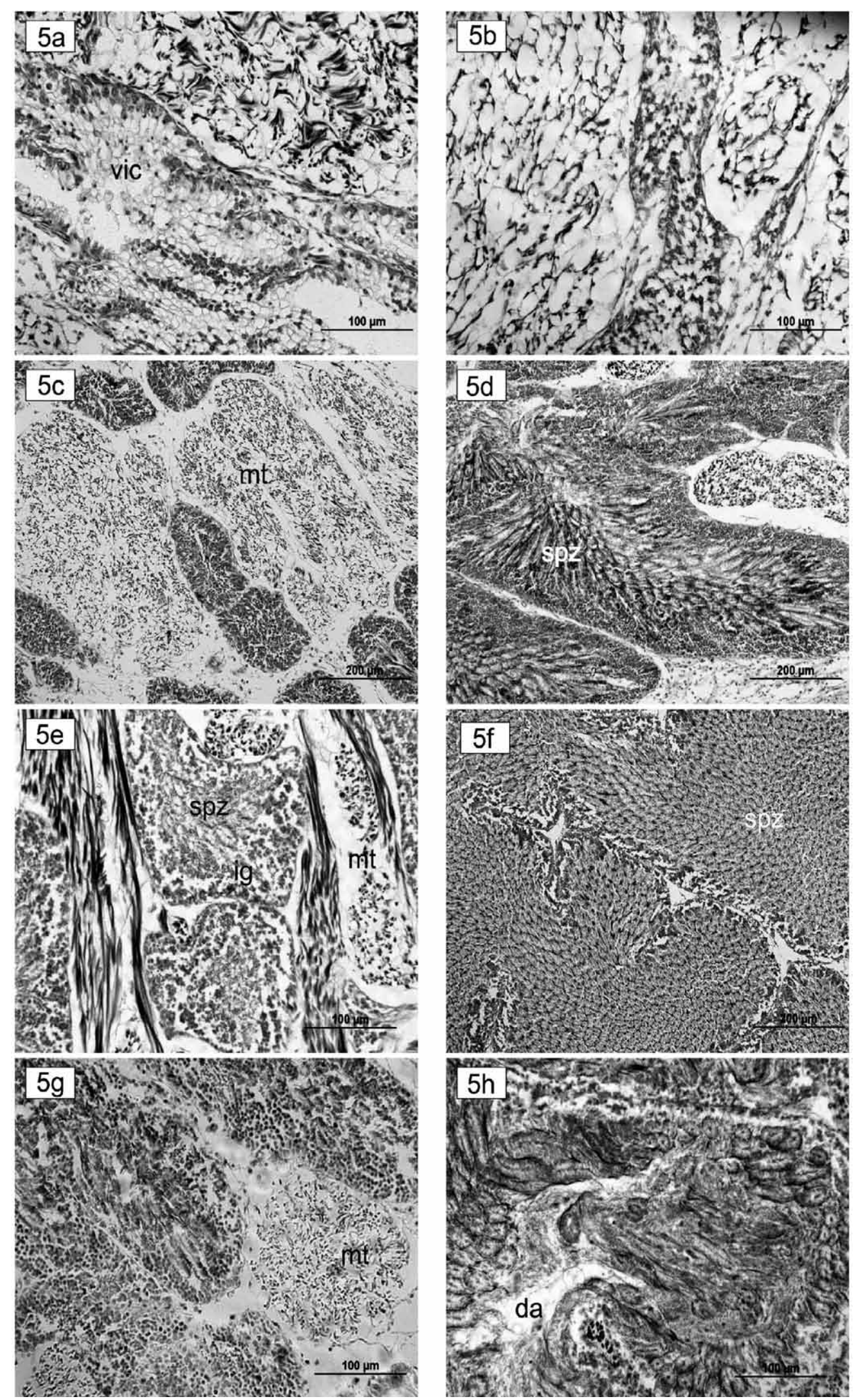

Fig. 5. - Gonadal development in males of $R$. decussatus. $5 \mathrm{a}$ and $5 \mathrm{~b}$ beginning of the experiment. Experiment $14^{\circ} \mathrm{C}: 5 \mathrm{c}, 32$ days; $5 \mathrm{e}, 57 \mathrm{days}$ : $5 \mathrm{~g}, 78$ days. Experiment $18^{\circ} \mathrm{C}$ : 5d, 32 days; $5 \mathrm{f}, 57$ days; $5 \mathrm{~h}, 78$ days. Abbreviations: da, disorganised acine; ig, immature gametes; mt, muscular tissue; spz, spermatozoids; vic, vesicular intrafollicular cells. Scale bar: $100 \mu \mathrm{m}$ (photos: 5a, 5b, 5e, 5g, 5h) and $200 \mu \mathrm{m}$ (photos: 5c, 5d, 5f). 

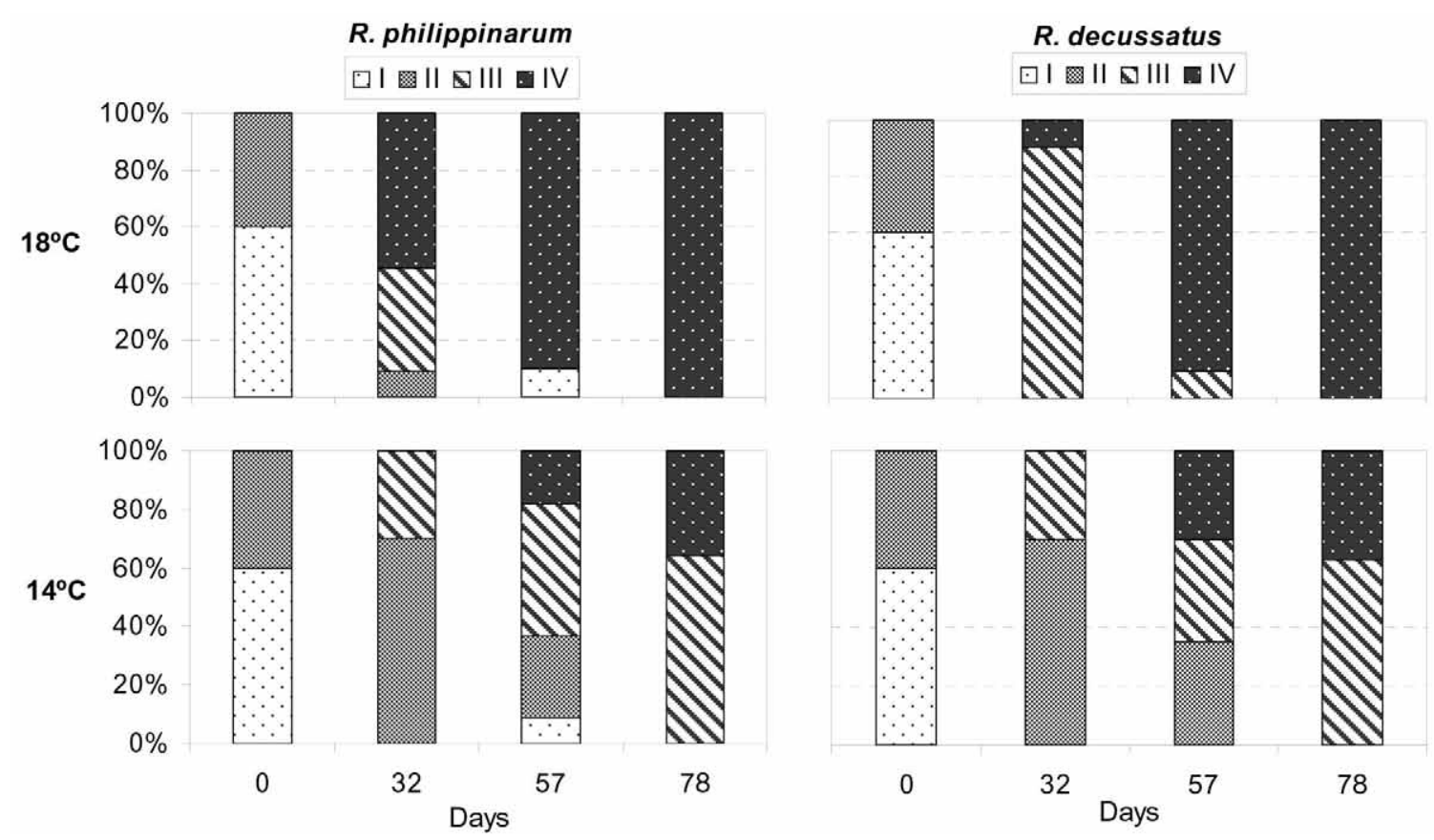

FIG. 6. - Distribution of the percentage of individuals at different phases of gonadal development (phases I, II, III and IV), for each species, experimental temperature and sampling.

the rest $(30 \%)$ being at phase III (Fig. 6 and 4c). However, at $18^{\circ} \mathrm{C}$, the great majority of individuals (90\%) had reached a phase of advanced gametogenesis (phase III), and some were fully mature (phase IV: $10 \%$; Fig. 6). The follicle walls were very active, showing a great proportion of pedunculated oocytes and some free mature oocytes in the lumina of the follicles (Fig. 4d). In males, the germinal layer was thick and also very active, showing spermatogonias and spermatocytes, with the interior of the acine being full of spermatozoids that had started to organise themselves in rosettes (Fig. 5d). The occasional male started to show signs of partial spawning.

After 57 days $35 \%$ of the population maintained at $14^{\circ} \mathrm{C}$ still remained at phase II of development, while $35 \%$ were at phase III and only $30 \%$ had reached phase IV (Figs. 4e and 5e). However, at $18^{\circ} \mathrm{C} 90 \%$ of the individuals were at phase IV. The follicles were full of oocytes obliging them to take on a polygonal outline, while in males the germinal layer was thinner and the acines were full of spermatozoids (Fig. 4f and 5f).

After 78 days of conditioning at $14^{\circ} \mathrm{C}$, over $60 \%$ of the individuals were still at phase III (Fig. $4 \mathrm{~g}$ and $5 \mathrm{~g}$ ) and only $37 \%$ of the experimental population had reached full maturity (phase IV). On the other hand, at $18^{\circ} \mathrm{C}, R$. decussatus was clearly mature, with $100 \%$ of the clams at phase IV. In females, the follicle walls were thin and there were commonly signs of partial emission of gametes (Fig. 4h). In males, the spermatozoids were arranged in rosettes and disorganised acines, the result of partial spawning, were easily recognisable (Fig. 5h).

At no time during the experiment, and for none of the conditions assayed with $R$. decussatus, did we observe any relevant reabsorption of haemocytes. Only sporadically could some degenerate oocytes (cytolysis) be seen, with no major haemocyte infiltration being apparent in the surrounding area.

In both species, reserve tissue formed by interfollicular muscle and vesicular cells (polygonal cells with an eccentric nucleus) was easily identified in the interior of the female follicles and male acines at the start of the experiments (Fig. 2a, 2b, 4b, 5a and $5 b)$. This tissue disappeared as the gonadal development advanced, and the velocity of disappearance was a direct function of temperature.

\section{Oocyte size-frequency distribution}

The data obtained confirm our histological observations, showing differences in gonadal maturation related to temperature in both species. Thus, after 32 days of conditioning the mean oocyte diameter in $R$. philippinarum at $14^{\circ} \mathrm{C}$ was $32.23 \mu \mathrm{m} \pm 4.84$, while at a temperature of $18^{\circ} \mathrm{C}$ it was $38.93 \mu \mathrm{m} \pm 3.89$, these differences being statistically significant $(\mathrm{t}-$ test, $\mathrm{p}<0.05$ ) (Fig. 7). A similar phenomenon 

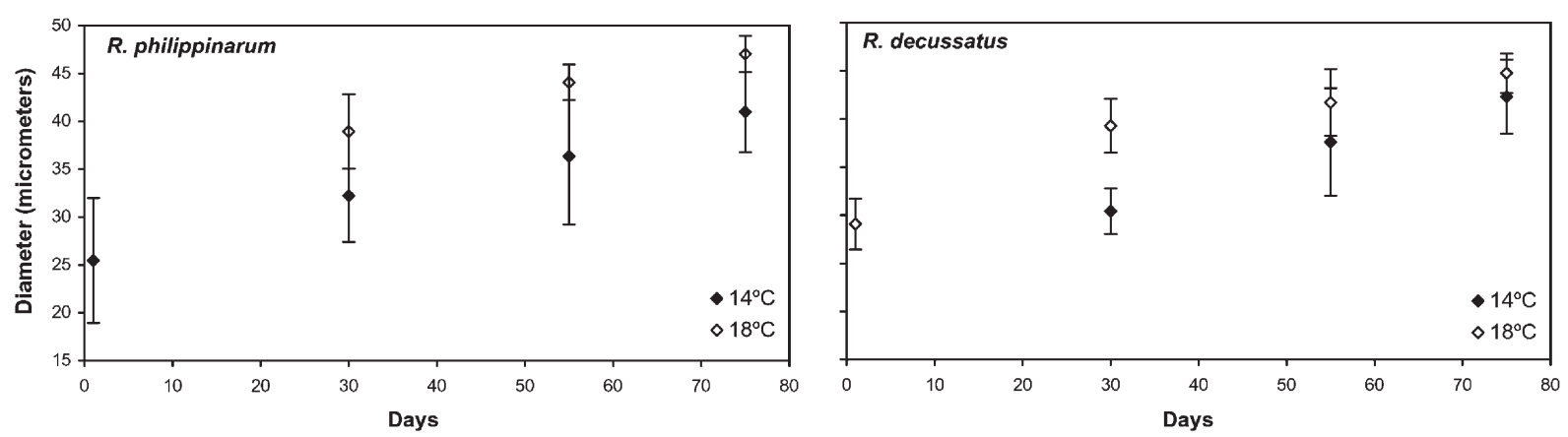

FIG. 7. - Variation in mean maximum diameter throughout the experiments at 14 and $18^{\circ} \mathrm{C}$ for R. philippinarum and R. decussatus.

occurred in the case of $R$. decussatus, mean oocyte diameters being $30.42 \mu \mathrm{m} \pm 2.37$ and $39.29 \mu \mathrm{m} \pm$ 2.80 , at 14 and $18^{\circ} \mathrm{C}$ respectively (t-test, $\mathrm{p}<0.05$ ) (Fig. 7).
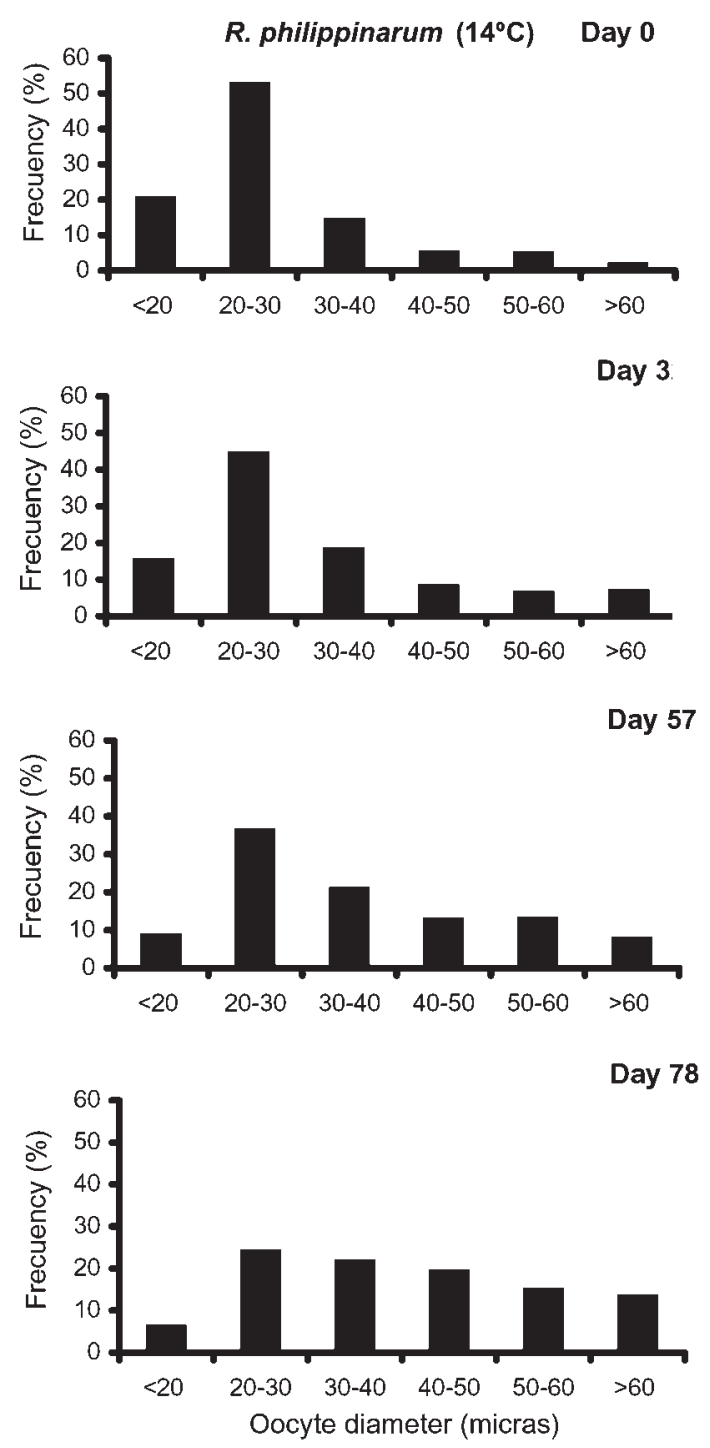

In the case of $R$. philippinarum, the skewness index (S), which initially stood at 0.73 , decreased over the conditioning period, showing a gradual increase in the proportion of oocytes of greater size
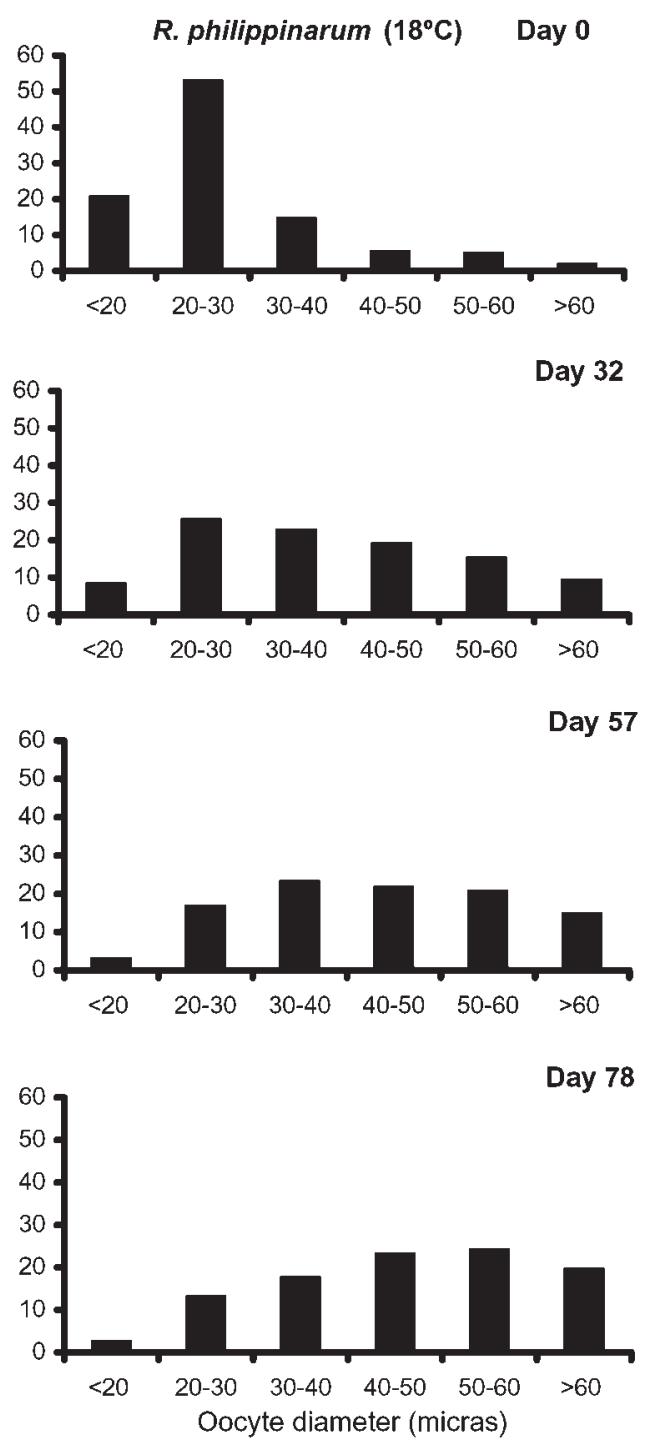

FIG. 8. - Frequency distribution of maximum oocyte diameters in R. philippinarum throughout the experiment at 14 and $18^{\circ} \mathrm{C}$. 
TABLE 2. - Descriptive parameters of size-frequency distributions of oocyte diameter for $R$. decussatus and R. philippinarum experiments at 14 and $18^{\circ} \mathrm{C}$. S: Skewness; K: Kurtosis.

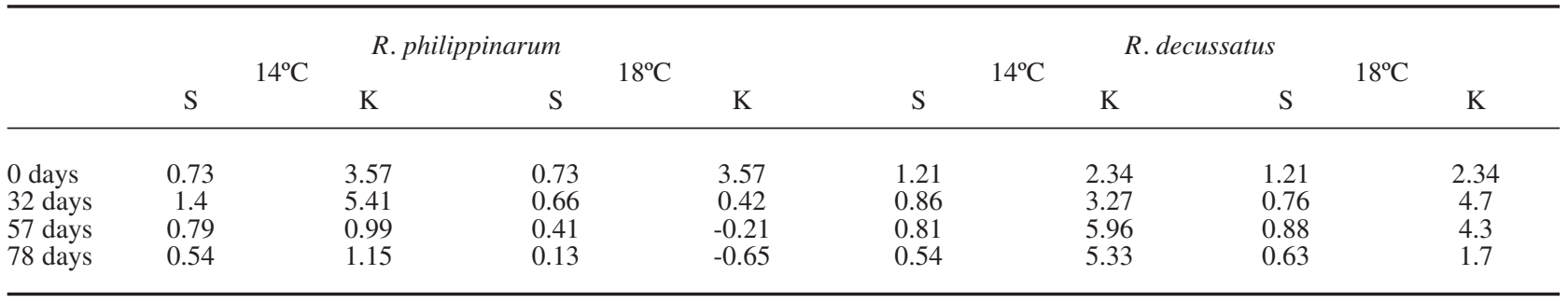
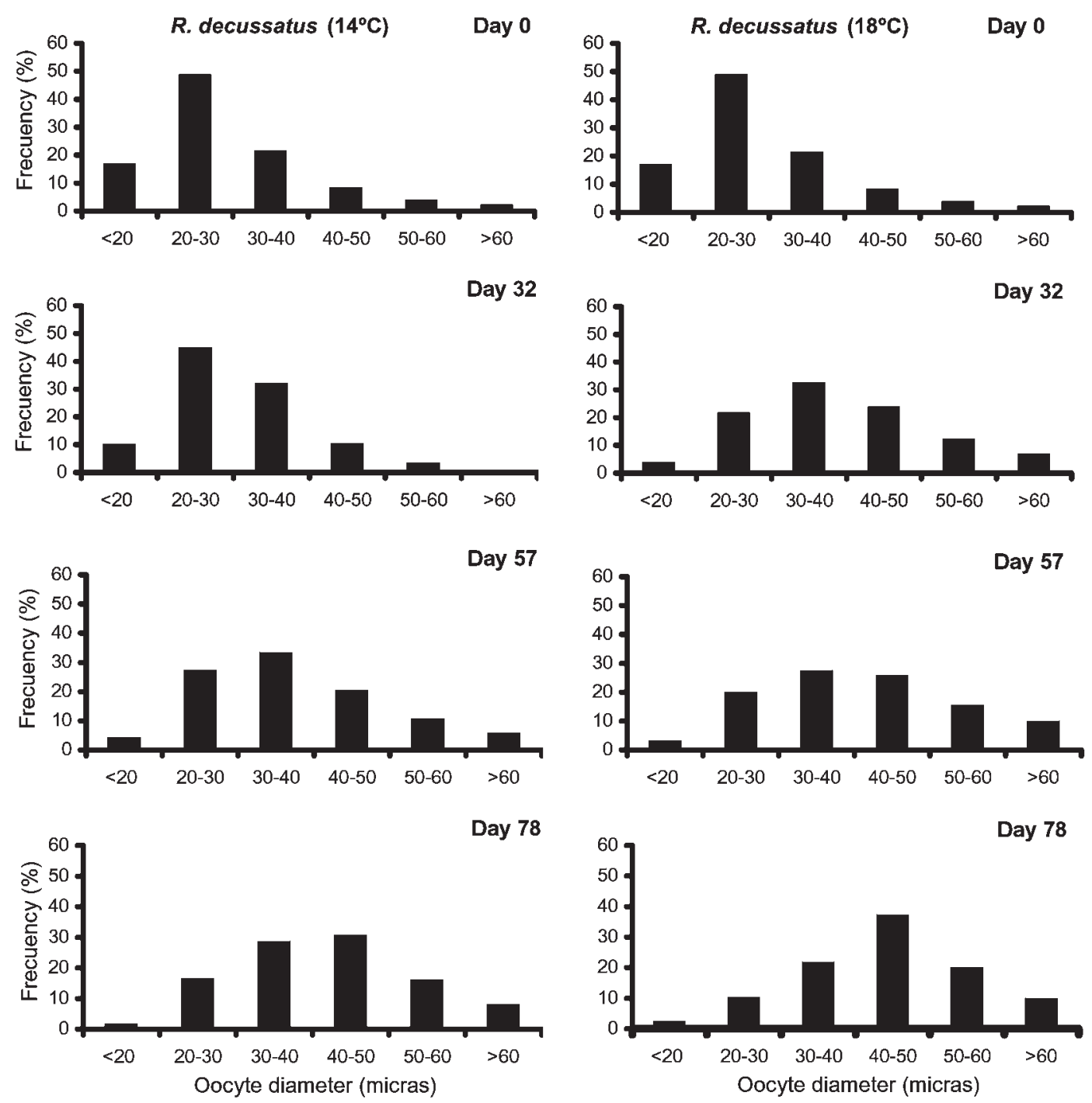

FIG. 9. - Frequency distribution of maximum oocyte diameters in $R$. decussatus throughout the experiment at 14 and $18^{\circ} \mathrm{C}$.

(Table 2). In fact, at $18^{\circ} \mathrm{C}$, the proportion of oocytes with mean diameter $>60 \mu \mathrm{m}$ came close to $20 \%$, with a skewness value of 0.13 (Fig. 8). Furthermore, the effect of temperature was clear, because although the index fell at $14^{\circ} \mathrm{C}$, it did so to a lesser extent than at $18^{\circ} \mathrm{C}(0.54)$.

In $R$. decussatus, initial skewness was 1.21 (Table 2), descending over the conditioning period and the accompanying maturation process to values ranging from $0.54\left(14^{\circ} \mathrm{C}\right)$ to $0.63\left(18^{\circ} \mathrm{C}\right)$. These levels were not so low as those for $R$. philippinarum, but there were no observable temperature-related differences that corresponded to those detected in the degree of maturation of the gonad during the histological study. This may possibly be related to the partial emissions of gametes, with the subsequent 
decrease in the percentage of larger oocytes, as is shown by the fact that at $18^{\circ} \mathrm{C}$, after 78 days of conditioning, the proportion of oocytes with a mean diameter $>60 \mu \mathrm{m}$ was no greater than $10 \%$ (Fig. 9).

The kurtosis values $(\mathrm{K})$, which indicate whether the distribution of data is more or less flat in comparison with a normal distribution, were initially high in $R$. philippinarum and then decreased as gonadal development progressed (Table 2). Values that approach zero, or are on occasions even negative, show that we have a more even size distribution with no single oocyte size predominating over the rest, i.e. there is a wide range of sizes and both young and mature oocytes are present in very similar proportions. $\mathrm{K}$ values for $R$. decussatus were greater than 1 , indicating the existence of steeper distribution curves in which certain size classes were predominant (Table 2).

If, at the end of the 78-day experimental period, we compare the distributions of the experiment performed at $18^{\circ} \mathrm{C}$ for both species, we can see that in $R$. philippinarum no single size class is particularly predominant (K: -0.65), while in $R$. decussatus, the 40$50 \mu \mathrm{m}$ class is present in greater proportion than the remaining size classes (K: 1.7) (Table 2, Fig. 8 and 9).

\section{DISCUSSION}

In both $R$. philippinarum and $R$. decussatus the gonadal development rate is directly related to the increase in temperature. At low temperatures $\left(14^{\circ} \mathrm{C}\right)$, such as those prevailing in spring on the Atlantic coast of northwest Spain (i.e. the Galician Rias) (Pérez-Camacho, 1980), the histological study performed indicates a very similar reproductive behaviour in both species, which take more than two months to reach reproductive maturity (phase IV). At $18^{\circ} \mathrm{C}$, a common summer temperature for the waters off the northwest seaboard of the Iberian Peninsula (Pérez-Camacho, 1980), R. philippinarum initially shows a higher gonadal development rate than $R$. decussatus. These differences, however, gradually decrease over time.

Despite the different origin and geographical distribution of the species in this experiment, the data reflected in the study reveal that both $R$. decussatus and $R$. philippinarum are perfectly adapted to the thermal conditions of the Galician Rias, allowing them to commence gonadal development in spring and reach full sexual maturity in summer. Indeed, the foreign species $R$. philippinarum may even possess a certain reproductive advantage over the native species $R$. decussatus as a result of its higher gonadal development rate.

The ability of $R$. philippinarum to produce mature oocytes at $14^{\circ} \mathrm{C}$ (as does $R$. decussatus), and the evidence of partial spawnings in our experiments performed at this temperature, enable it to adapt to cold water environments, and our findings in this regard coincide with those of several authors for the natural environment (Beninger and Lucas, 1984; Rodríguez-Moscoso et al., 1992). Some authors, in their studies of $R$. philippinarum in the natural environment, have pointed out that the lowest temperature limit at which spawning is possible in this species is $14^{\circ} \mathrm{C}$, a point which has also been proved in the present study. The low limit for maturation of gametes would be $12^{\circ} \mathrm{C}$, while $8^{\circ} \mathrm{C}$ would be the lowest temperature at which gametogenesis could commence (Ohba, 1959; Holland and Chew, 1974; Mann, 1979; Xie and Burnell, 1994).

The native species $R$. decussatus is also well adapted to a wide range of temperatures, its geographical distribution reaching the Mediterranean and Adriatic Seas and stretching in the eastern Atlantic from the British Isles to the coast of Senegal (Vilela, 1950; Tebble, 1966).

If we consider the statistics that describe oocyte size-frequency distribution, at the beginning of the experimental period skewness values were 0.73 in $R$. philippinarum and 1.21 in $R$. decussatus, thus indicating a greater proportion of small oocytes (25-27 $\mu \mathrm{m}$; Figs. 8 and 9) in both species as compared with the rest of the experiment. As the experiment continued and gonadal maturation progressed, mean oocyte diameter increased and skewness values dropped to almost zero, as the proportion of larger oocytes rose. These indices are similar to those given by Meneghetti et al. (2004) in their study of the reproductive cycle of $R$. philippinarum in the Lagoon of Venice.

When the gonad is mature, $R$. philippinarum shows a highly homogeneous distribution of oocyte size classes, with no single size standing out above the rest, whereas $R$. decussatus shows a more heterogeneous oocyte size-frequency distribution and its most numerous size class is that of $40-50 \mu \mathrm{m}$.

These data support the interpretation given by Laruelle et al. (1994) in their comparative study of the same two species in their natural environment in Brittany (France), according to which $R$. philip- 
pinarum undergoes an accumulation of oocytes prior to partial or total emissions, while in $R$. decussatus gametes appear to be released continuously. This behaviour may also explain the absence of differences in skewness values between the two experimental temperatures in the case of $R$. decussatus.

As has been described by various authors (Xie and Burnell, 1994; Delgado, 2002; Meneghetti et al., 2004; Drummond et al., 2006), there is a high degree of asynchronicity between individuals regarding gonadal development in the two species, and it can therefore be hard to assign a specific reproductive phase to a given population of either one. In the case of $R$. philippinarum this asynchronicity is transferred to the gonad itself, with three different reproductive phases frequently being found within the same individual. This heterogeneity of gonadal development is more obvious in the earliest phases of development and tends to disappear as the gonad matures. When an individual is fully mature it shows a single reproductive phase, with all follicles then being at phase IV. The gonadal development between individuals of $R$. decussatus is more homogeneous than in the former species.

A further major difference between the two species is the phenomenon of reabsorption, which occurs to a high degree in $R$. philippinarum but hardly ever in $R$. decussatus (Delgado and PérezCamacho, 2005). The reabsorption process is particularly intense in the period of sexual rest, where we found a multitude of haemocyte infiltrations that cleaned and reabsorbed unemitted gametes from a previous gonadal maturation. Once these follicles have been cleaned, their walls start to develop new germinal lines, temperature permitting, or else accumulate reserves (vesicular cells) if food and temperature conditions so determine.

Some authors confine reabsorption phenomena, or a state of gonadal restoration, to post-total spawning phases at the end of the gonadal cycle (Drummond et al., 2006). Medhioub (1986) locates this phenomenon after the final spawnings and detects invasions of granulocytes in the gonadal tubules surrounding the residual gametes, which atrophy and return the gonad to a state of sexual rest. In our case, however, this phenomenon was observed throughout the entire maturation process at both 14 and $18^{\circ} \mathrm{C}$, disappearing only when the individual was fully mature. The clams at the beginning of the experimental period, given the degree of reabsorption and number of residual gametes observed, may well be in a transition phase between postspawning, or a state of sexual rest, and the start of a new gametogenic cycle. Along these lines, Rodríguez-Moscoso et al. (1992), in his study of the reproductive cycle of the $R$. philippinarum clam, cites the appearance of haemocyte infiltrations and gamete reabsorption in some individuals of this species at times that do not coincide with full gonadal maturation (January, February, May, July and October for males; December-March and November-December for females).

Medhioub (1986) and Sarasquete et al. (1990) are of the opinion that the vesicular cells that appear at the commencement of gametogenesis originate from cells resulting from haemocyte differentiation. Lysis of the vesicular cells, together with the atrophy and degeneration of the smooth muscle cells adjacent to the gonadal tubules, liberate metabolites for the purpose of covering the energy needs of gametogenesis. In both species the vesicular cells disappear completely while lysis of the muscle cells is never total, as mentioned by authors such as Delgado and PérezCamacho (2005), Medhioub (1986), RodríguezMoscoso et al. (1992) and Rodríguez-Moscoso and Arnaíz (1998). Furthermore, the disappearance of vesicular cells occurs earlier in females than in males. These vesicular cells liberate glucose and products of lipid catabolism (Medhioub, 1986). Atrophied and degenerate muscle cells supply protein and glucide metabolites, which may be used directly by the cells of the germinal line or absorbed by granulocytes and supplied at a later moment to maintain the reproductive effort (Medhioub and Lubet, 1988). As mentioned above, the persistence of reabsorption figures in $R$. philippinarum both in the phase of sexual rest, where this is more apparent, and throughout the process of gonadal maturation, is evidence of the high capacity for gametogenic regeneration in this species and its ability to recover the energy invested in the production of unemitted gametes.

This greater capacity for gonadal regeneration in $R$. philippinarum, coupled with its higher rate of gonadal development, may account for this species' greater reproductive activity and longer reproductive period than $R$. decussatus, as described by Beninger and Lucas (1984), Rodrigues-Carballo et al. (1992) and Laruelle et al. (1994), and this may even represent a certain adaptive advantage of the foreign species ( $R$. philippinarum) over the native species (R. decussatus) in the temperature conditions of the Galician Rias. 


\section{ACKNOWLEDGEMENTS}

We would like to thank C. Rodríguez, C. Pena and P. Mallo for their technical assistance. This study was financed by the projects AGL2004-07023-CO201/ACU and PGIDITO5PXIC60401PN.

\section{REFERENCES}

Bancroft, J.D. and A. Stevens. - 1996. Theory and practice of histological techniques. Churchill Livingstone, Nueva York.

Beninger, P.G. and A. Lucas. - 1984. Seasonal variations in condition, reproductive activity, and gross biochemical composition of two species of adult clam reared in a common habitat Tapes descussatus L. (Jeffreys) and Tapes philippinarum (Adams and Reeve). J. Exp. Mar. Biol. Ecol., 79(1): 19-37.

Delgado, M. - 2002. Maduración sexual en Ruditapes decussatus (L.): Implicaciones energéticas y bioquímicas. Ph. D. thesis, Univ. Santiago de Compostela.

Delgado, M. and A. Pérez-Camacho. - 2005. Histological study of the gonadal development of Ruditapes decussatus (L.): (Mollusca: Bivalvia) and its relationship with available food. Sci.Mar., 69(1): 87-97.

Drummond, L., M. Mulcahy, and S. Culloty. - 2006. The reproductive biology of the Manila clam, Ruditapes philippinarum, from the North-West of Ireland. Aquaculture, 254: 326-340.

Holland, D.A. and K.K. Chew. - 1974. Reproductive cycle of the Manila clam (Venerupis japonica) from Hood Canal, Washington. Proc. Nat. Shell. Assoc., 64: 53-58.

Laruelle, F.J., J. Guillou and Y.M. Paulet. - 1994. Reproductive pattern of the clams, Ruditapes decussatus and Ruditapes philippinarum on intertidal flats in Brittany. J. Mar. Biol. Assoc. U.K., 74(2): 351-366.

Mann, R. - 1979. The effect of temperature on growth, physiology and gametogenesis in the Manila clam Tapes philippinarum (Adams and Reeve, 1850). J. Exp. Mar. Biol.Ecol., 38: 121-133.

Medhioub, N.M. - 1986. Recherches cytologiques sur le cycle de reproduction et l'évolution des réserves chez la palourde japonaise. $\mathrm{Ph}$. D. thesis, Univ. Caen.

Medhioub, N.M. and P. Lubet. - 1988. Recherches cytologiques sur l'environment cellulaire (tissu de réserve) des gonades de la Palourde (Ruditapes philippinarum Adams and Reeve), Mollusque bivalve. Ann. Sci. Nat. Zool., 13e Série, 9: 87-102.

Meneghetti, F., V. Moschino and L. Da Ros. - 2004. Gametogenic cycle and variations in oocyte size of Tapes philippinarum form the Lagoon of Venice. Aquaculture, 240: 473-488.

Ohba, S. - 1959. Ecological studies in the natural population of a clam, Tapes japonica, with special reference to seasonal variations in the size and structure of the population and to individual growth. Biol. J. Okayama. Univ., 5: 13-47.

Pérez-Camacho, A. - 1980. Biología de Venerupis pullastra
(Montagu, 1803) y Venerupis decussata (Linné, 1767) (Mollusca: Bivalvia) con especial referencia a factores determinantes de la producción. Bol. Inst. Esp. Oceanogr., 281: 353-358.

Ponurovsky, S.K. and Y.M. Yakovlev. - 1992. The reproductive biology of the Japanese littleneck, Tapes philippinarum (Adams and Reeve, 1850) (Bivalvia: Veneridae). J. Shellfish Res., 11(2): 265-277.

Rodrigues-Carballo, S., R. Quintana-Carballo, F.J. Ferreiro, J. Velasco Selas and P. López. - 1992. Evaluación del ciclo reproductor de Ruditapes philippinarum y Tapes decussatus en la Ría de Muros-Noya. Alimentaria, 236: 37-44.

Rodríguez-Moscoso, E., J.P. Pazo, A. Garcia and F. FernándezCortes. - 1992. Reproductive cycle of Manila clam, Ruditapes philippinarum (Adams and Reeve, 1850) in Ria of Vigo (NW Spain). Sci.Mar., 56(1): 61-67.

Rodríguez-Moscoso, E. and R. Arnaíz. - 1998. Gametogenesis and energy storage in a population of the grooved carpet-shell clam, Tapes decussatus (Linne, 1787) in northwest Spain. Aquaculture, 162: 125-139.

Sarasquete, M.C., S. Gimeno and M.L. González de Canales. - 1990. Cycle reproducteur de la palourde Ruditapes philippinarum (Adams and Reeve, 1850) de la côte sud ouest atlantique (Espagne). Rev. Int. Océannogr. Med., LXXXXVII, 90-99.

Shaffee, M.S. and M. Daouidi. - 1991. Gametogenesis and spawning in the carpet-shell clam, Ruditapes decussatus (L.) (Mollusca: Bivalvia), from the Atlantic coast of Morocco. Aquacult. Fish Manage., 22: 203-216.

Snedecor, G.W. and W.G. Cochran. - 1980. Métodos estadísticos. Cía Ed. Continental, Buenos Aires.

Tebble, N. - 1966. British Bivalve Seashells. British Museum (Natural History), London.

Toba, M., Y. Natsume and H. Yamakawa. - 1993. Reproductive cycle of Manila clam from Funabashi waters, Tokyo Bay. Nippon Suisan Gakkaishi, 59(1): 15-22.

Toba, M. and Y. Miyama. - 1995. Influence of temperature on the sexual maturation in Manila clam, Ruditapes philippinarum. Jpn Aquac. Soc., 43(3): 305-314.

Villalba, A., M.J. Carballal and M.C. López. - 1993. Estudio del ciclo gonadal de tres especies de almeja, Ruditapes decussatus, Venerupis pullastra y Venerupis rhomboides de las rías gallegas. Actas IV Congreso Nac. Acuicutura, 341-346.

Vilela, H. - 1950. Vida bentónica de Tapes decussatus (L.). Trav. Sta. Biol. Marit. Lisbonne, $\mathrm{n}^{\circ} 53$.

Walne, P.R. - 1966. Experiments in the large-scale culture of the larvae of Ostrea edulis (L.). Fish. Invest., Series II., XXIV(1): $1-45$.

Xie, Q. and G.M. Burnell. - 1994. A comparative study of the gametogenic cycles of the clams Tapes philippinarum (Adams and Reeve, 1850) and Tapes decussatus (Linnaeus) on the south coast of Ireland. J. Shellfish Res., 13(2): 467-472.

Zar, J.H. - 1974. Biostatistical analysis. Prentice-Hill. Englewood Cliffs, N. J.

Scient. ed.: M. Gaspar.

Received November 16, 2006. Accepted April 12, 2007.

Publilshed online June 28, 2007. 